\title{
Progesterone, Follicular, and Estrual Responses to Progesterone-Based Estrus and Ovulation Synchronization Protocols at Five Stages of the Estrous Cycle ${ }^{1}$
}

\author{
J. S. Stevenson ${ }^{2}$ \\ Department of Animal Sciences and Industry, Kansas State University, Manhattan 66506-0201
}

\begin{abstract}
The objective was to monitor changes in ovarian status in heifers exposed to a progesterone insert with or without concurrent GnRH injection. Estrus was manipulated in 283 heifers (31 breeding clusters) by administering $\mathrm{GnRH}$, progesterone, and $\mathrm{PGF}_{2 \alpha}$ at 5 stages of the estrous cycle. Estrus was presynchronized with a progesterone insert (CIDR) for $7 \mathrm{~d}$ before $\mathrm{PGF}_{2 \alpha}$ was administered $24 \mathrm{~h}$ before insert removal. Successive clusters of heifers were assigned to treatments (2 heifers per treatment) on cycle d 2, 5, 10, 15, and 18. Treatments consisted of a progesterone insert (d 0) for $7 \mathrm{~d}$ plus: 1) $\mathrm{PGF}_{2 \alpha}$ on $\mathrm{d} 6,24 \mathrm{~h}$ before insert removal (early PGF); 2) GnRH on d 0 + early $\mathrm{PGF}_{2 \alpha}(\mathrm{GnRH}+$ early PGF); 3) $\mathrm{PGF}_{2 \alpha}$ at insert removal (late $\mathrm{PGF}$ ); and 4) GnRH on d 0 + late PGF (GnRH + late PGF). Controls received $\mathrm{GnRH}$ on $\mathrm{d} 0$ and $\mathrm{PGF}_{2 \alpha}$ on $\mathrm{d} 7$. Ovaries were scanned by transrectal ultrasonography on d 0,2 , 7, 9, and 11 to assess follicle diameters and ovulation. Blood was collected on d $0,2,6,7,8$, and 9 to quantify serum concentrations of progesterone. Insemination occurred after detected estrus or by timed artificial insemination (TAI) at $64 \mathrm{~h}$ after insert removal. Only $25 \%$ of $141 \mathrm{GnRH}$-treated heifers ovulated by d 2; twice as many ovulated when treatment was initiated on $\mathrm{d} 5$ (46.4\%) than on other cycle days (20.3\%). Diameters of the largest follicle exposed to GnRH on d 0,2 , 7, or 9 did not differ regardless of whether ovulation occurred. Small treatment and stage of cycle differences in diameter of the largest follicle were detected on $\mathrm{d} 2,7$, and 9. Compared with controls, progesterone concentration was greater in all progesterone-treated heifers on $\mathrm{d} 2$ and 6. Early- vs. late-PGF treatment resulted in less
\end{abstract}

\footnotetext{
Received May 20, 2008.

Accepted July 20, 2008

${ }^{1}$ Contribution number 08-367-J from the Kansas Agricultural Experiment Station, Manhattan 66506. I acknowledge former graduate students who helped conduct this study (C. A. Blevins, M A. Portaluppi, D. E. Tenhouse, S. F. Tiffany, M. G. Burns, and B. S. Buttrey) as well as Irene Vanderwerff, who performed all of the laboratory work.

${ }^{2}$ Corresponding author: jss@ksu.edu
}

progesterone on $\mathrm{d} 7$ and 8 . Pregnancies per AI were less after TAI (44\%) than after detected estrus (56\%) and were less in controls than in all progesterone treatments. Heifers in which treatments were initiated on d 10 of the cycle had the most consistent (estrus vs. TAI) pregnancies per AI (65.4\%) compared with other cycle days. Compared with controls, more progesteronetreated heifers ovulated by $96 \mathrm{~h}$ after insert removal. Application of the progesterone insert reduced variance of the interval to estrus after insert removal (or $\mathrm{PGF}_{2 \alpha}$ injection in controls) by 1.6-fold compared with controls. These results do not support the use of $\mathrm{GnRH}$ in a progesterone-based synchronization protocol.

Key words: follicle, gonadotropin-releasing hormone, heifer, progesterone

\section{INTRODUCTION}

Synchronization of estrus, ovulation, or both in lactating dairy (Pursley et al., 1997; Nebel and Jobst, 1998) and beef cows (Lamb et al., 2001; Patterson et al., 2003) has become practical during the past few years by applying variations of the Ovsynch protocol (GnRH injection $7 \mathrm{~d}$ before and $48 \mathrm{~h}$ after an injection of $\mathrm{PGF}_{2 \alpha}$ ) with or without addition of a progesteronereleasing intravaginal controlled internal drug release (CIDR) insert.

A timed AI (TAI) protocol for heifers that provides consistently acceptable pregnancy rates is lacking. Attempts to use the Ovsynch protocol as a TAI protocol for dairy heifers have proved disappointing (Pursley et al., 1997; Stevenson et al., 2000) because of poor fertility of heifers with premature expression of estrus between the first GnRH injection and $\mathrm{PGF}_{2 \alpha}$. When estrus occurs prematurely after $\mathrm{PGF}_{2 \alpha}$, a single TAI will not produce a high likelihood of conception (Stevenson et al., 2000; Richardson et al., 2002). Most heifer developers in the beef and dairy industries desire acceptable protocols that employ TAI.

Earlier research in heifers using a progesteronereleasing intravaginal device (PRID; Smith et al., 1984), norgestomet implants (Stevenson et al., 2000), and the CIDR insert (Richardson et al., 2002) confirms 
the benefit of using a progestin to prevent premature expression of estrus. Expression of estrus in heifers was reported in those studies after various treatment combinations of progestins (PRID for 6 or $7 \mathrm{~d}$, norgestomet for $7 \mathrm{~d}$, or CIDR for $7 \mathrm{~d}$, respectively) and $\mathrm{PGF}_{2 \alpha}$ given at or $24 \mathrm{~h}$ before progestin withdrawal. Estrus tended to be more closely synchronized in heifers treated with $\mathrm{PGF}_{2 \alpha} 24 \mathrm{~h}$ before progestin withdrawal than in those treated with $\mathrm{PGF}_{2 \alpha}$ concurrent with progestin removal or with $\mathrm{PGF}_{2 \alpha}$ alone. When $\mathrm{PGF}_{2 \alpha}$ was injected $24 \mathrm{~h}$ before removal of the PRID or norgestomet, $76 \%$ of treated heifers were in estrus during a 24-h period (Hansel and Beal, 1979).

A recent study in beef heifers employed GnRH, progesterone (CIDR), and $\mathrm{PGF}_{2 \alpha}$ and combinations of detected estrus before AI, TAI, or both (Lamb et al., 2006). In that 12-location study, the treatment in which $\mathrm{GnRH}$ was administered concurrently with a 7-d progesterone insert, and TAI conducted at 60 $\mathrm{h}$ after insert removal and $\mathrm{PGF}_{2 \alpha}$ injection produced most consistently the best pregnancies per AI (P/AI) across locations. Necessity of the upfront GnRH injection is questionable because small differences (2.8 to 4 percentage points) in $\mathrm{P} / \mathrm{AI}$ were detected for heifers receiving and not receiving that injection (Lamb et al., 2006).

The hypothesis of the current experiment was that including a progestin in a $\mathrm{GnRH}+\mathrm{PGF}_{2 \alpha}$ protocol could prevent premature expression of estrus to facilitate TAI without loss of fertility. Variation in fertility may depend on effectiveness of the upfront $\mathrm{GnRH}$ injection to ovulate a dominant follicle. Further, turnover of a dominant follicle in nulliparous heifers is less successful than in lactating dairy cows (Pursley et al., 1995), and little is known about follicle turnover or ovulatory response to $\mathrm{GnRH}$ in heifers treated concurrently with progesterone. When stage of the estrous cycle was known in heifers at the time of GnRH injection, in absence of a progesterone insert (Moreira et al., 2000 ), the proportions of follicles that ovulated after GnRH were as follows: d $2(0 / 5 ; 0 \%)$; d $5(5 / 5 ; 100 \%)$; d $10(1 / 4 ; 25 \%)$; d $15(3 / 5 ; 60 \%)$; and d $18(5 / 5 ; 100 \%)$. Moreover, $54.2 \%(13 / 24)$ of heifers ovulated in response to an injection of GnRH administered at random stages of the estrous cycle (Pursley et al., 1995), but ovulation incidence averaged $63 \%$ in lactating dairy cows (Vasconcelos et al., 1999).

The objective of the current study was to assess follicular responses, ovulation, luteal function (concentrations of progesterone in serum), and incidences of estrus in response to combinations of $\mathrm{GnRH}, \mathrm{PGF}_{2 \alpha}$, and progesterone applied for synchronization of estrus, ovulation, or both in nulliparous, replacement heifers. An ancillary objective was to monitor P/AI to deter- mine if a TAI protocol was feasible after using protocols consisting of $\mathrm{GnRH}, \mathrm{PGF}_{2 \alpha}$, and progesterone.

\section{MATERIALS AND METHODS}

\section{Experimental Heifers}

Holstein heifers ranging in age from 11.6 to 16.5 mo $(13.3 \pm 0.95$ mo; mean $\pm \mathrm{SD})$ and $\mathrm{BW}$ from 315 to $501 \mathrm{~kg}(410 \pm 34 \mathrm{~kg}$; mean $\pm \mathrm{SD})$ were housed at the Kansas State University Dairy Teaching and Research Center, Manhattan, and maintained on dry lots with covered free stalls and a concrete feed apron. Heifers were fed a TMR consisting of chopped prairie or alfalfa hay, corn or milo grain, soybean meal, and minerals and vitamins to exceed NRC (2001) guidelines for growing heifers.

\section{Experimental Approach}

Estrous cycles of dairy heifers (electronic estrus-detection patches were applied; HeatWatch, Cow Chips, LLC, Denver, CO) were presynchronized by placing a progesterone insert containing $1.38 \mathrm{~g}$ of progesterone (Eazi-Breed CIDR, Pfizer Animal Health, New York, $\mathrm{NY}$ ) for $7 \mathrm{~d}$ and administering $25 \mathrm{mg}$ of $\mathrm{PGF}_{2 \alpha}$ (Lutalyse, Pfizer Animal Health, New York, NY) 24 h before insert removal. After detection of estrus, heifers were assigned randomly to treatment schemes at 5 stages of the estrous cycle: $\mathrm{d} 2,5,10,15$, and 18 . These stages represent major expected sources of variation in intervals to estrus (combinations of maturity of dominant follicles when the insert is removed and presence or absence of a CL that is responsive to luteolysis; Moreira et al., 2000) after removal of progesterone or injection of $\mathrm{PGF}_{2 \alpha}$.

Between February 2003 and March 2006, estrous cycles of 31 clusters of heifers (10 heifers per cluster except for 8 clusters that varied in size from 5 to 12 heifers) were presynchronized as described previously to initiate treatments in a rotating pattern starting on cycle d 2, 5, 10, 15, and 18 and then repeated that pattern during the course of the experiment. Generally, 2 heifers per cluster were assigned randomly to each of 5 treatment schemes (Figure 1) consisting of a progesterone insert (d 0) for $7 \mathrm{~d}$ plus: 1) $25 \mathrm{mg}$ of $\mathrm{PGF}_{2 \alpha}$ (Lutalyse) on $\mathrm{d} 6,24 \mathrm{~h}$ before insert removal (early PGF); 2) $100 \mu \mathrm{g}$ of GnRH (Cystorelin, Merial, Athens, GA) on d $0+\mathrm{PGF}_{2 \alpha}$ on d $6(\mathrm{GnRH}+$ early $\mathrm{PGF})$; 3) $\mathrm{PGF}_{2 \alpha}$ at insert removal (d 7; late PGF); and 4) $100 \mu \mathrm{g}$ of $\mathrm{GnRH}$ on d 0 + late $\mathrm{PGF}_{2 \alpha} \cdot(\mathrm{GnRH}+$ late $\mathrm{PGF}$ ); or 5) controls, which only received GnRH on d 0 and $\mathrm{PGF}_{2 \alpha}$ on $\mathrm{d} 7$.

Blood was collected from a coccygeal blood vessel on d $0,2,6,7,8$, and 9 (Figure 1). Blood sera concentra- 


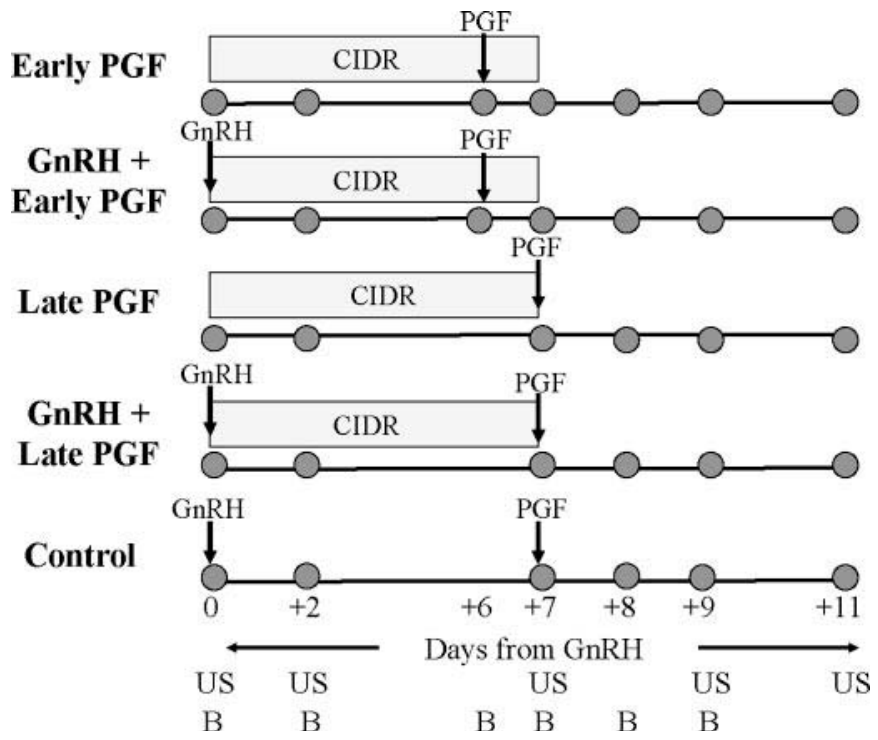

Figure 1. Experimental design of treatments. All treatments except control included a 7-d progesterone insert with or without a concurrent injection of $\mathrm{GnRH}$. An injection of $\mathrm{PGF}_{2 \alpha}(\mathrm{PGF})$ was given at insert removal or $24 \mathrm{~h}$ earlier. Control heifers received $\mathrm{GnRH}$ followed in $7 \mathrm{~d}$ by $\mathrm{PGF}_{2 \alpha}$. CIDR $=1.38 \mathrm{~g}$ of progesterone controlled internal drug release insert; $\mathrm{GnRH}=100 \mu \mathrm{g}$ of $\mathrm{GnRH} ; \mathrm{PGF}=25 \mathrm{mg}$ of $\mathrm{PGF}_{2 \alpha} ; \mathrm{US}=$ transrectal ultrasonography; and $\mathrm{B}=$ blood collection.

tions of progesterone were later quantified by radioimmunoassay (Skaggs et al., 1986). Inter- and intra-assay coefficients of variation for 16 assays were 6.2 and $5.4 \%$, respectively, in a pooled sample that averaged $3.82 \pm$ $0.04 \mathrm{ng} / \mathrm{mL}$ (replicated 3 times in each 160-sample assay). Luteal regression was assessed by examining concentrations of progesterone on d 7, 8, and 9. Only heifers having reduced concentrations $(<1 \mathrm{ng} / \mathrm{mL})$ by $48 \mathrm{~h}$ after insert removal or those that were reduced on all $3 \mathrm{~d}(\mathrm{~d} 7,8$, and 9) were considered to have had luteal regression.

Ovaries were examined by transrectal ultrasonography on $\mathrm{d} 0,2,7,9$, and 11 from initiation of each synchronization treatment to assess diameter of all follicles $>5 \mathrm{~mm}(\mathrm{~d} 0,2,6,7$, and 9), evidence for ovulation on d 2 in heifers treated with GnRH on d 0 , and evidence for post-AI ovulation (d 11 or $96 \mathrm{~h}$ after insert removal).

Heifers were inseminated either based on standing estrus (detected by HeatWatch) or at $63.7 \pm 0.8(\mathrm{SD}) \mathrm{h}$ (range of 61 to $65 \mathrm{~h}$ ) after removal of the insert. Characteristics and incidence of estrus (duration of estrus, number of standing events, and duration of standing time) were determined from HeatWatch software.

Pregnancy was diagnosed by transrectal ultrasonography at 32 or $33 \mathrm{~d}$ after AI. Presence of a viable embryo (heart beat) was evidence for a confirmed pregnancy. Pregnancies per AI were calculated as number of heif- ers pregnant after AI divided by total number of heifers inseminated.

\section{Statistical Analyses}

Discrete, binomial variables $(\mathrm{P} / \mathrm{AI}$; ovulation after $\mathrm{GnRH}$ injection or treatment AI; relationship between onset of estrus and AI; and percentages of heifers having concentrations of progesterone $\geq 1 \mathrm{ng} / \mathrm{mL}$ at 0 , 24 , and $48 \mathrm{~h}$ after insert removal and luteal regression) were analyzed by logistic regression (procedures GLM and GENMOD in SAS; SAS Institute Inc., Cary, NC). For $\mathrm{P} / \mathrm{AI}$, the model included treatment $(\mathrm{n}=5)$, stage of estrous cycle $(\mathrm{n}=5)$, TAI ( 0 vs. 1$)$, all 2-way interactions, plus age and $\mathrm{BW}$ at the onset of treatment as covariates. A priori contrasts were constructed to test the effect of early vs. late injection of $\mathrm{PGF}_{2 \alpha}$ and effect of GnRH vs. no GnRH among progesterone-treated heifers and progesterone insert vs. control. Models to test other binomial variables were similar but excluded the TAI variable.

Orthogonal unequally spaced polynomial coefficients were generated for stages of the estrous cycle (d 2, 5, 10,15 , and 18) to examine the relationship of incidence of luteal regression with stage of cycle using procedure IML in SAS.

Continuous variables (largest follicle diameter, characteristics of estrus, and concentrations of progesterone) were analyzed by ANOVA (procedure GLM of SAS); the model included treatment, stage of the estrous cycle, treatment $\times$ stage interaction, and age and BW at the onset of treatment as covariates. For the largest follicle diameter and concentrations of progesterone, models were sorted by day and then analyzed for each experimental day (d 0, 2, 7, and 9 for follicle data and d 2, 6, 7, 8, and 9 for progesterone data). A priori contrasts were constructed to test the effects of early vs. late injection of $\mathrm{PGF}_{2 \alpha}$, GnRH vs. no GnRH among progesterone-treated heifers, and progesterone insert vs. control.

\section{RESULTS}

\section{Follicular Characteristics and Ovulatory Responses}

Heifers in 2 treatments received GnRH concurrent with insertion of the progesterone insert; the control (no progesterone) received $\mathrm{GnRH}$ at the same time. The proportion of heifers with new ovulatory structures was evaluated $48 \mathrm{~h}$ after $\mathrm{GnRH}$ injection. Only $25.1 \%$ of 141 heifers had new luteal structures, and a new CL was detected $48 \mathrm{~h}$ after progesterone treatment in 1 heifer on cycle d 2 (Table 1 ). Proportions were similar among the 3 treatments in which $\mathrm{GnRH}$ was adminis- 
Table 1. Incidence of ovulation after GnRH and posttreatment based on stage of cycle at onset of treatment

\begin{tabular}{|c|c|c|}
\hline \multirow[b]{2}{*}{ Item } & \multicolumn{2}{|c|}{$\%$ ovulation $^{1}$ (no.) } \\
\hline & Response to $\mathrm{GnRH}^{2}$ & Posttreatment $^{2}$ \\
\hline \multicolumn{3}{|l|}{ Treatment $^{2}$} \\
\hline Early $\mathrm{PGF}_{2 \alpha}$ & $2.1^{\mathrm{a}}(47)$ & $91.5^{\mathrm{a}}(47)$ \\
\hline $\mathrm{GnRH}+$ early $\mathrm{PGF}_{2 \alpha}$ & $28.9^{\mathrm{b}}(45)$ & $88.9^{\mathrm{a}}(45)$ \\
\hline Late $\mathrm{PGF}_{2 \alpha}$ & $0.0^{\mathrm{a}}(47)$ & $89.4^{\mathrm{a}}(47)$ \\
\hline $\mathrm{GnRH}$ + late $\mathrm{PGF}_{2 \alpha}$ & $18.8^{\mathrm{b}}(48)$ & $89.6^{\mathrm{a}}(48)$ \\
\hline Control & $29.2^{\mathrm{b}}(48)$ & $68.8^{\mathrm{b}}(48)$ \\
\hline \multicolumn{3}{|l|}{ Day of estrous cycle ${ }^{3}$} \\
\hline 2 & $21.4^{\mathrm{a}}(28)$ & $75.6^{\mathrm{ab}}(45)$ \\
\hline 5 & $46.4^{\mathrm{b}}(28)$ & $78.0^{\mathrm{a}}(50)$ \\
\hline 10 & $18.5^{\mathrm{a}}(27)$ & $100.0^{\mathrm{c}}(45)$ \\
\hline 15 & $24.1^{\mathrm{a}}(29)$ & $87.8^{\mathrm{bc}}(49)$ \\
\hline 18 & $17.2^{\mathrm{a}}(29)$ & $87.0^{\mathrm{bc}}(46)$ \\
\hline
\end{tabular}

${ }^{\mathrm{a}-\mathrm{c}}$ Mean percentages within column and item with different superscript letters differ $(P<0.05)$.

${ }^{1}$ Determined by transrectal ultrasonographic evidence of follicle disappearance and presence of new luteal tissue at $48 \mathrm{~h}$ after $\mathrm{GnRH}$ injection or at $96 \mathrm{~h}$ after progesterone insert removal.

${ }^{2}$ All treatments except control included a 7-d progesterone insert with or without a concurrent injection of $\mathrm{GnRH}$, and $\mathrm{PGF}_{2 \alpha}$ was given either at insert removal or $24 \mathrm{~h}$ earlier. Control heifers received GnRH followed in $7 \mathrm{~d}$ by $\mathrm{PGF}_{2 \alpha}$.

${ }^{3}$ Stage of estrous cycle at onset of treatment. Excludes heifers in GnRH + early $\mathrm{PGF}_{2 \alpha}$ and $\mathrm{GnRH}+$ later $\mathrm{PGF}_{2 \alpha}$ heifers that did not receive a GnRH injection.

tered. More $(P<0.05)$ heifers ovulated on cycle d 5 than at any other stage of the cycle. No interaction was detected between stage of cycle and treatment. Concurrent administration of progesterone via the insert did not reduce subsequent ovulation because proportions of control heifers having a new luteal structure $48 \mathrm{~h}$ after GnRH: d $2(22.2 \%, 2 / 9)$; d $5(55.6 \%, 5 / 9)$; d $10(11.1 \%$, $1 / 9)$; d $15(30 \%, 3 / 10)$; and d $18(27.2 \%, 3 / 11)$ were similar to $\mathrm{GnRH}$ and progesterone-treated heifers: $\mathrm{d} 2$ $(21.1 \%, 4 / 19)$; d $5(42.1 \%, 8 / 19)$; d $10(22.2 \%, 4 / 18)$; d $15(21.1 \%, 4 / 19)$; and d 18 (11.1\%, 2/18).

No interaction between treatment and stage of cycle was detected for diameters of largest follicles examined on experimental d 0, 2, 7, and 9. Diameter of the largest follicle (putative dominant follicle) was similar among treatments on $\mathrm{d} 0$ and did not differ regardless of whether ovulation occurred (Table 2). The largest follicle on d 2, 7, and 9 did not differ between groups of heifers that did or did not ovulate in response to $\mathrm{GnRH}$ (Table 2). Among treatments for heifers not receiving GnRH (early PGF $=9.4 \pm 0.7 \mathrm{~mm}$ and late PGF $=$ $8.3 \pm 0.6 \mathrm{~mm}$ ), diameter of the largest follicle on $\mathrm{d} 2$ after progesterone insert was greater $(P<0.05)$ than that in heifers receiving $\mathrm{GnRH}(\mathrm{GnRH}+$ early $\mathrm{PGF}=$ $6.6 \pm 0.6 \mathrm{~mm} ; \mathrm{GnRH}+$ late $\mathrm{PGF}=7.5 \pm 0.6 \mathrm{~mm}$; and control $=7.1 \pm 0.6 \mathrm{~mm}$ ). By d 7 and 9 , diameter of the largest follicle did not differ among treatments.

Regardless of treatments, stage of estrous cycle at onset of treatments influenced largest follicle diameter on experimental d 2 because late-cycle heifers (d $15=$ $9.4 \pm 0.6 \mathrm{~mm}$ and $\mathrm{d} 18=8.6 \pm 0.6 \mathrm{~mm})$ had larger $(P$ $<0.05)$ follicles than cycle d 10 heifers $(6.1 \pm 0.7 \mathrm{~mm})$. By d 7, these differences were negligible, but by d 9 , the largest follicle was greater $(P<0.05)$ in diameter for heifers initiating treatment on cycle d $2(13.5 \pm 0.4$ $\mathrm{mm}), 10(13.3 \pm 0.4 \mathrm{~mm})$, and $18(14.6 \pm 0.5 \mathrm{~mm})$ compared with cycle d $5(11.7 \pm 0.4 \mathrm{~mm})$.

\section{Progesterone}

Concentrations of progesterone assessed on experimental d 0, 2, 6, 7, 8, and 9 are illustrated in Figure 2. At the onset of treatment, concentration of progesterone did not differ among heifers assigned to various treatments. By $48 \mathrm{~h}$ after onset of treatment, progesteronetreated heifers had greater $(P<0.001)$ concentrations than controls. This difference $(P<0.05)$ persisted until d 6 , but among progesterone-treated heifers, those that received GnRH tended $(P=0.08)$ to have greater concentrations of progesterone than those not treated with GnRH. On d 7, $24 \mathrm{~h}$ after early PGF heifers were injected with $\mathrm{PGF}_{2 \alpha}$, progesterone was reduced compared with late PGF heifers. By d 8, $24 \mathrm{~h}$ after insert removal, early PGF heifers tended $(P=0.08)$ to maintain lower concentrations of progesterone than late PGF heifers. By d 9, all progesterone-treated heifers had less $(P<$ 0.001) progesterone than controls.

Table 2. Largest follicle diameters in heifers that ovulated or did not ovulate in response to GnRH at onset of treatment

\begin{tabular}{lcr}
\hline & \multicolumn{2}{c}{ Ovulation incidence $^{1}$ (no.) } \\
\cline { 2 - 3 } Day of treatment & \multicolumn{1}{c}{ No } & \multicolumn{1}{c}{ Yes } \\
\hline Onset of treatment, d 0 & $12.0 \pm 0.4^{2}(74)$ & $12.1 \pm 0.5(35)$ \\
48 h after GnRH, d 2 & $7.6 \pm 0.3(75)$ & $6.5 \pm 0.7(18)$ \\
Progesterone insert removal, d 7 & $11.7 \pm 0.3(101)$ & $11.1 \pm 0.5(34)$ \\
48 h after progesterone insert removal, d 9 & $13.8 \pm 0.3(95)$ & $13.3 \pm 0.4(35)$ \\
\hline
\end{tabular}

${ }^{1}$ Determined by transrectal ultrasonography at $48 \mathrm{~h}$ after $\mathrm{GnRH}$ injection. Excludes heifers in treatments in which no GnRH was administered at the onset of treatment.

${ }^{2}$ Least squares means $\pm \mathrm{SE}$. 


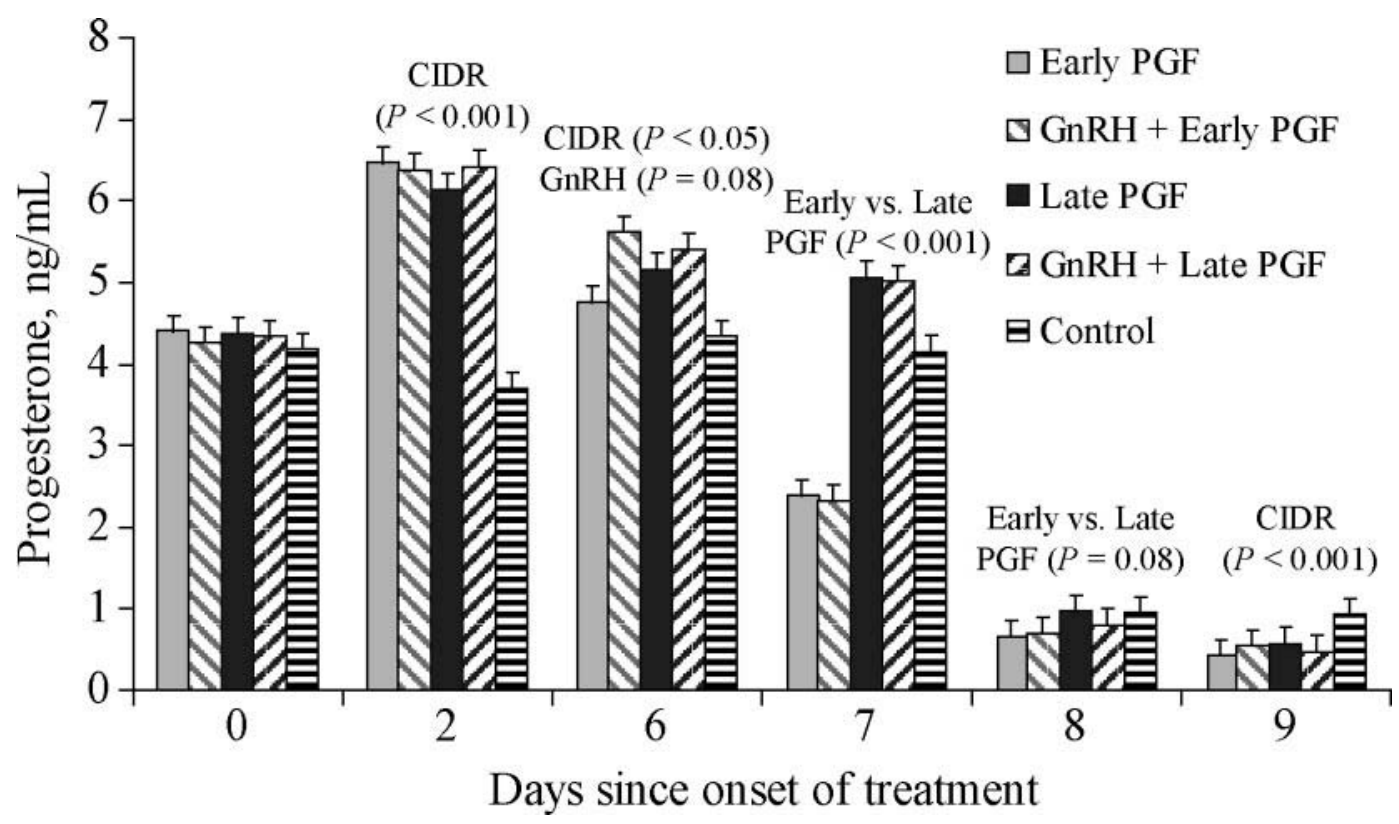

Figure 2. Treatment effects on concentrations of progesterone beginning at the onset of treatment (d 0$)$ until $2 \mathrm{~d}$ after progesterone insert removal. All treatments except control included a 7-d insert with or without a concurrent injection of $\mathrm{GnRH}_{\text {. An injection of PGF }}\left(\mathrm{PGF}_{2 \alpha}\right.$ was given at insert removal or $24 \mathrm{~h}$ earlier. Control heifers received $\mathrm{GnRH}$ followed in $7 \mathrm{~d}$ by $\mathrm{PGF}_{2 \alpha}$. Five treatments were: early PGF ( $\mathrm{n}=56$ ), $\mathrm{GnRH}+$ early PGF $(\mathrm{n}=56)$, late PGF $(\mathrm{n}=55), \mathrm{GnRH}+$ late PGF $(\mathrm{n}=60)$, and control $(\mathrm{n}=55)$. Contrasts are as follows: progesterone insert (CIDR) vs. control, GnRH vs. no GnRH (progesterone insert treatments only), and early vs. late PGF.

Predictable stage of cycle effects on serum concentrations of progesterone are illustrated in Figure 3. No treatment $\times$ stage of cycle interactions occurred except on $\mathrm{d} 7(P<0.001)$ as a result of the earlier luteolysis in the early PGF treatment.
Luteolysis was assessed by examining the proportion of heifers having concentrations of progesterone $<1 \mathrm{ng} /$ $\mathrm{mL}$ by $48 \mathrm{~h}$ after insert removal. On experimental d 7 (just before insert removal), proportion of controls having elevated progesterone was less $(P<0.05)$ than for

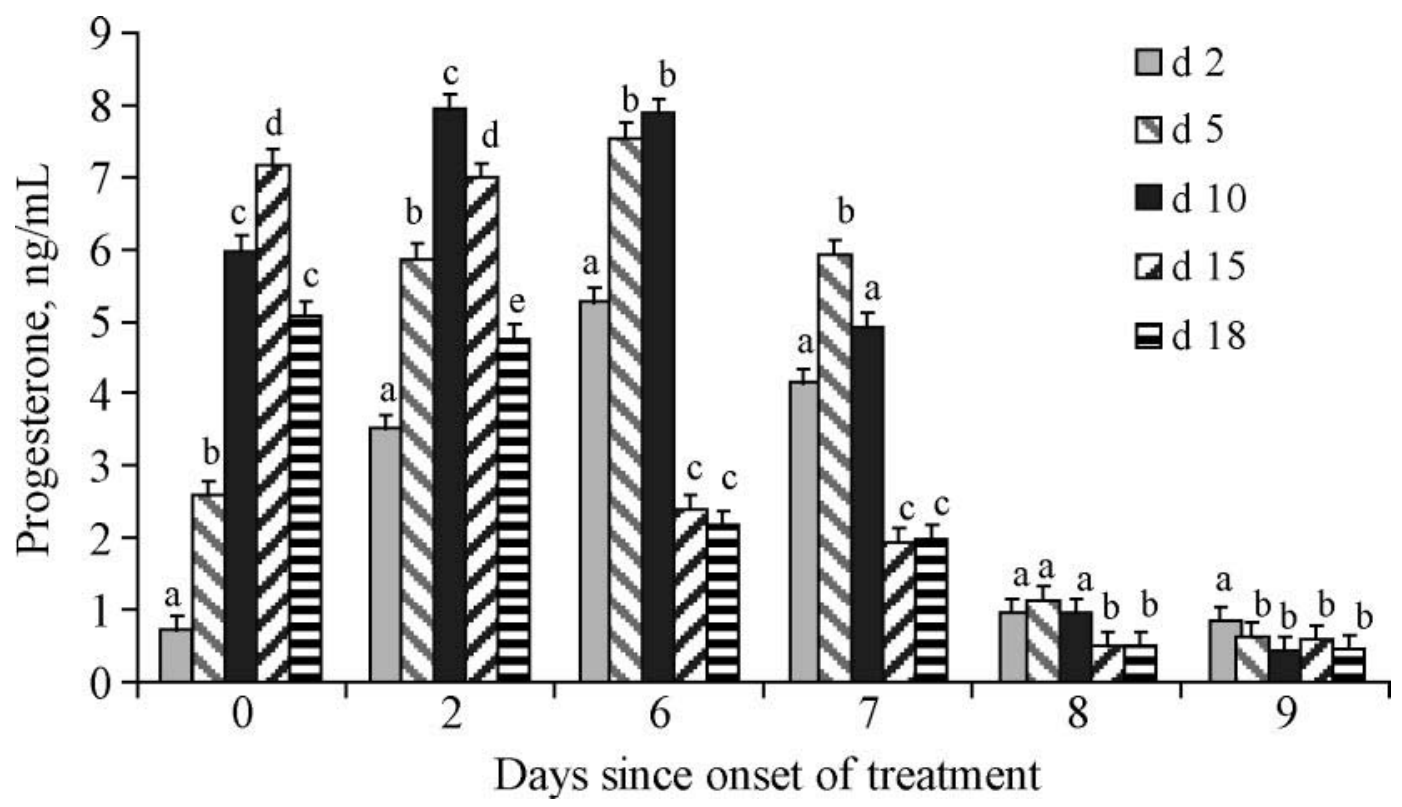

Figure 3. Concentrations of progesterone in heifers at various days of the estrous cycle when treatments were initiated: $\mathrm{d} 2$ ( $\mathrm{n}=55)$; $\mathrm{d} 5$ ( $\mathrm{n}$ $=61) ; \mathrm{d} 10(\mathrm{n}=56) ; \mathrm{d} 15(\mathrm{n}=57)$; and $\mathrm{d} 18(\mathrm{n}=53) .{ }^{\mathrm{a}-\mathrm{e}}$ Means within experimental day having different letters differ $(P<0.05)$. 


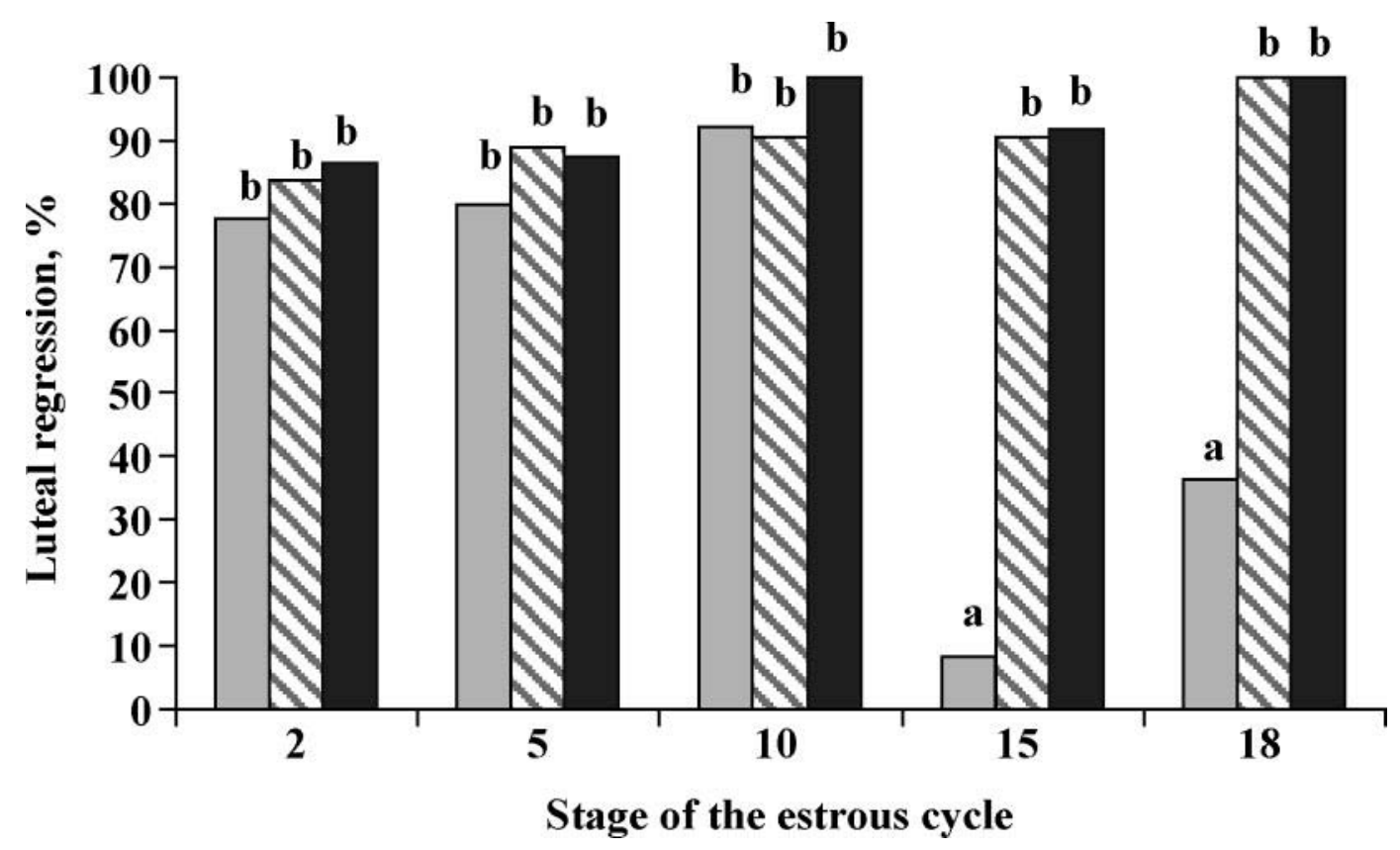

Figure 4. Luteal regression in heifers in which concentration of progesterone was $\geq 1 \mathrm{ng} / \mathrm{mL}$ at progesterone insert removal (d 7 ) and $<1$ $\mathrm{ng} / \mathrm{mL} 48 \mathrm{~h}$ later. All treatments except control included a 7-d progesterone insert with or without a concurrent injection of GnRH. An injection of $\mathrm{PGF}_{2 \alpha}$ was given at insert removal (dark solid bars; $\mathrm{n}=115$ ) or $24 \mathrm{~h}$ earlier (stippled bars; $\mathrm{n}=112$ ). Control heifers received GnRH followed in $7 \mathrm{~d}$ by $\mathrm{PGF}_{2 \alpha}$ (light solid bars; $\mathrm{n}=55$ ). ${ }^{\mathrm{a}, \mathrm{b}}$ Bars within stage of cycle having different letters differ $(P<0.05)$.

progesterone treatments ( 72.7 vs. $97.8 \%$, respectively). By d 8, $48 \mathrm{~h}$ after early $\mathrm{PGF}_{2 \alpha}$ injection or $24 \mathrm{~h}$ after late PGF injection, fewer $(P<0.05)$ early PGF heifers had elevated progesterone compared with later PGF and control heifers (9.8 vs. 30.4 vs. $32.7 \%$, respectively) treated with $\mathrm{PGF}_{2 \alpha}$ on d 7 . By d 9 (48 or $72 \mathrm{~h}$ after $\mathrm{PGF}_{2 \alpha}$ ), more control heifers had incomplete luteolysis (25.5 vs. $6.2 \%)$ than all progesterone-treated heifers. This difference was related to early or no luteolysis in controls in which treatments were initiated on cycle d 15 and 18. Proportions of controls on experimental d 9 having elevated progesterone for cycle d 2, 5, 10, 15, and 18 were $22.2,10,0,58.3$, and $36.4 \%$, respectively, indicating that progesterone-treated heifers had less incidences of incomplete luteolysis or total luteolytic failure than controls.

The majority $(18 / 23 ; 78.3 \%)$ of luteolytic failures occurred in controls that initiated treatment on cycle d 15 or 18 (Figure 4). Regardless of treatment, however, luteolytic failures for heifers initiating treatment on d 2 (16\%), 5 (13\%), 10 (5\%), 15 (26\%), and 18 $(13 \%)$ were greatest $(P<0.05)$ for d 15 . Orthogonal polynomial curves fit to the average incidence of luteal regression across treatments were significant for linear $(P=0.02)$, cubic $(P=0.006)$, and quartic $(P=0.005)$ relationships. The linear relationships best described the increase in luteolysis for cycle d 2, 5, and 10 heifers that were on cycle d 9, 12, and 17 when inserts were removed.

\section{Characteristics of Estrus}

Distribution of estrus after insert removal on experimental d 7 is illustrated in Figure 5. Included in this comparison are combined treatment responses and presynchronizaton response of all heifers (pre-early PGF) in which heifers received a progesterone insert for 7 $\mathrm{d}$ and $\mathrm{PGF}_{2 \alpha}$ was injected $24 \mathrm{~h}$ before insert removal (as early PGF treatment). Injection of $\mathrm{GnRH}$ on $\mathrm{d}$ 0 had no effect on onset of estrus; thus, the 2 early PGF treatments were combined as were the 2 late PGF treatments.

Among progesterone-treated heifers, distribution of estrus was shifted slightly to the left for those treated with $\mathrm{PGF}_{2 \alpha} 24 \mathrm{~h}$ before insert removal compared with those receiving $\mathrm{PGF}_{2 \alpha}$ at insert removal. Both the preearly PGF and early PGF (treated similar to pre-early PGF) had similar distribution patterns. Mean intervals to estrus were $44.8 \pm 2.1$ (pre-early PGF), $45.3 \pm 3.2$ (early PGF), $52.6 \pm 3.3$ (late PGF), and $33.4 \pm 4.8 \mathrm{~h}$ (control). Variances were: $1,013,829,768$, and 2,718, respectively. Variance of the first 3 groups was less $(P$ $<0.001)$ than that of the control (Levene's test). Distribution pattern of controls was more variable because no progesterone insert was used to prevent premature expression of estrus in heifers started on treatment on cycle d 15 and 18.

Average intervals to estrus after treatment and other characteristics of estrus are summarized in Table 3 . 


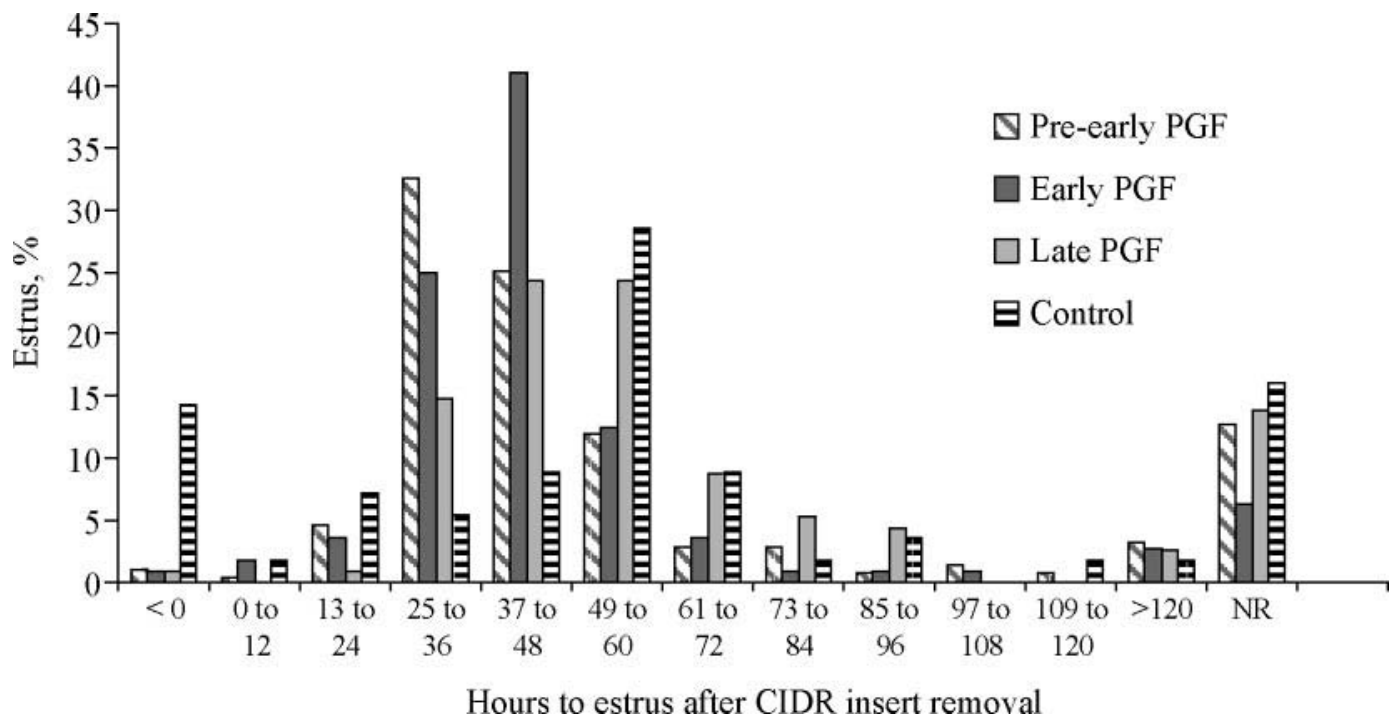

Figure 5. Distribution of estrus after early administration of $\mathrm{PGF}_{2 \alpha}$ (PGF; $24 \mathrm{~h}$ before a 7-d progesterone insert was removed from all heifers during pretreatment synchronization of estrus; $\mathrm{n}=247)$, early $\mathrm{PGF}_{2 \alpha}(24 \mathrm{~h}$ before insert removal) during treatment $(\mathrm{n}=105)$, late $\mathrm{PGF} 2 \mathrm{P}$ concurrent with insert removal $(\mathrm{n}=99)$, or in controls $\left(\mathrm{GnRH} 7 \mathrm{~d}\right.$ before $\left.\mathrm{PGF}_{2 \alpha} ; \mathrm{n}=47\right)$.

Although heifers receiving $\mathrm{PGF}_{2 \alpha} 24 \mathrm{~h}$ before insert removal were in estrus 2 to $10 \mathrm{~h}$ earlier than comparable late PGF heifers, interval to estrus did not differ. Controls had a shorter $(P<0.05)$ interval to estrus than all heifers receiving progesterone inserts. Variances also differed $(P<0.001)$ among treatments and were
1.3 to 1.6 greater in control than progesterone treatments. Duration of estrus, number of standing events, and total duration of standing events were increased $(P$ $<0.05)$ in progesterone-treated heifers that received GnRH. Stage of estrous cycle effects were detected for interval to estrus (longer for cycle d 5 than for cycle $d$

Table 3. Characteristics of estrus after treatment and according to stage of the estrous cycle

\begin{tabular}{|c|c|c|c|c|c|}
\hline Item & $\begin{array}{c}\text { Heifers, } \\
\text { no. }\end{array}$ & $\begin{array}{l}\text { Progesterone insert } \\
\text { removal to estrus, } h\end{array}$ & $\begin{array}{l}\text { Duration } \\
\text { of estrus, } h\end{array}$ & $\begin{array}{l}\text { Standing } \\
\text { events, no. }\end{array}$ & $\begin{array}{l}\text { Total duration of } \\
\text { standing events, } \mathrm{s}\end{array}$ \\
\hline \multicolumn{6}{|l|}{ Treatment $^{1}$} \\
\hline Early $\mathrm{PGF}_{2 \alpha}$ & 52 & $51 \pm 4^{\mathrm{a}}$ & $10 \pm 1^{\mathrm{ab}, \mathrm{x}}$ & $20 \pm 3^{\mathrm{a}, \mathrm{x}}$ & $43 \pm 6^{\mathrm{ab}, \mathrm{x}}$ \\
\hline \multicolumn{6}{|l|}{$\mathrm{PGF}_{2 \alpha}$} \\
\hline Late $\mathrm{PGF}_{2 \alpha}$ & 46 & $53 \pm 4^{\mathrm{a}}$ & $10 \pm 1^{\mathrm{a}, \mathrm{x}}$ & $19 \pm 3^{\mathrm{a}, \mathrm{x}}$ & $39 \pm 6^{\mathrm{b}, \mathrm{x}}$ \\
\hline GnRH + Late $\mathrm{PGF}_{20}$ & 53 & $51 \pm 4^{\mathrm{a}}$ & $12 \pm 1^{\mathrm{b}, \mathrm{y}}$ & $25 \pm 2^{\mathrm{ab}, \mathrm{y}}$ & $54 \pm 6^{\mathrm{ab}, \mathrm{y}}$ \\
\hline Late $\mathrm{PGF}_{2 \alpha}$ & 99 & $53 \pm 3$ & $11 \pm 0.6$ & $22 \pm 2$ & $47 \pm 4$ \\
\hline \multicolumn{6}{|l|}{ Day of estrous cycle ${ }^{3}$} \\
\hline 2 & 49 & $55 \pm 4^{\mathrm{ab}}$ & $12 \pm 1^{\mathrm{a}}$ & $25 \pm 3^{\mathrm{a}}$ & $50 \pm 6^{\mathrm{ab}}$ \\
\hline 5 & 57 & $62 \pm 4^{\mathrm{a}}$ & $11 \pm 1^{\mathrm{ab}}$ & $25 \pm 2^{\mathrm{a}}$ & $54 \pm 6^{\mathrm{a}}$ \\
\hline 10 & 52 & $48 \pm 4^{\mathrm{b}}$ & $10 \pm 1^{\mathrm{ab}}$ & $17 \pm 3^{\mathrm{b}}$ & $38 \pm 6^{\mathrm{b}}$ \\
\hline
\end{tabular}

${ }^{\mathrm{a}-\mathrm{c}}$ Means within column and item having different superscript letters differ $(P \leq 0.05)$.

${ }^{\mathrm{x}, \mathrm{y}}$ Progesterone-treated heifers receiving GnRH differed $(P \leq 0.05)$ from those progesterone-treated heifers not receiving GnRH.

${ }^{z}$ Controls had a shorter $(P \leq 0.05)$ interval to estrus than all progesterone treatments.

${ }^{1}$ All treatments except control included a 7-d CIDR insert with or without a concurrent injection of GnRH, and PGF $2 \alpha$ was given either at insert removal or $24 \mathrm{~h}$ earlier. Control heifers received $\mathrm{GnRH}$ followed in $7 \mathrm{~d}$ by $\mathrm{PGF}_{2 \alpha}$. Interval to estrus in controls was that between $\mathrm{PGF}_{2 \mathrm{a}}$ and estrus.

${ }^{2}$ Levene's test revealed that the variance in interval to estrus was greater $(P<0.001)$ for controls compared with progesterone treatments.

${ }^{3}$ Stage of estrous cycle at onset of treatment. 
10,15 , and 18). Generally, longer $(P<0.05)$ duration of estrus and more $(P<0.05)$ standing events of longer total duration were detected in heifers initiating treatment on d 2, 5, and 18 compared with cycle d 10 and 15 (Table 3).

Posttreatment ovulation by $96 \mathrm{~h}$ after insert removal is reported in Table 1. Incidence of ovulation was less $(P<0.05)$ in controls compared with progesterone treatments. Day of cycle at which treatment was initiated affected $(P=0.001)$ ovulation. Least incidence of posttreatment ovulation occurred in heifers initiating treatment on cycle d 2, and the best incidence of ovulation was detected in cycle d 10 heifers. Reduced posttreatment ovulation in control heifers was a result of premature expression of estrus and early ovulation before treatment with $\mathrm{PGF}_{2 \alpha}$ and more luteolytic failures (Figure 4).

\section{Pregnancies per Al}

Pregnancies per AI were recorded, but inadequate numbers of heifers were treated to detect potential differences in fertility. Nonetheless, $\mathrm{P} / \mathrm{AI}$ in control heifers differed $(P<0.05)$ from heifers that received progesterone and $\mathrm{P} / \mathrm{AI}$ after TAI were less $(P<0.05)$ than in heifers inseminated after detected estrus. Numerically greater $\mathrm{P} / \mathrm{AI}$ were observed in late PGF $(51.5 \%)$ than early PGF $(41.3 \%)$ treatments regardless of $\mathrm{GnRH}$ administration. Cycle d 10 heifers had the most consistent $\mathrm{P} / \mathrm{AI}$ exceeding $65 \%$ regardless of whether insemination occurred after detected estrus or by appointment.

The relationship between onset of estrus and when semen was placed into the uterus of heifers is illustrated in Figure 6 . The P/AI were generally greater when estrus occurred between 30 and $0 \mathrm{~h}$ before AI. For heifers inseminated more than $30 \mathrm{~h}$ before onset of estrus or those detected in estrus after $\mathrm{AI}, \mathrm{P} / \mathrm{AI}$ were clearly reduced $50 \%$ or more.

\section{DISCUSSION}

One objective was to determine ovarian follicular responses to $\mathrm{GnRH}$ and subsequent ovulation after treatment. Injection of $\mathrm{GnRH}$ was rather ineffective in inducing ovulation in dairy heifers (Table 1) compared with earlier reports in dairy (Pursley et al., 1995; Moreira et al., 2000) and beef heifers (Atkins et al., 2008). Collectively, $45 \%$ of beef heifers ovulated in response to GnRH (Atkins et al., 2008) compared with 54.2\% of dairy heifers (Pursley et al., 1995) and 25\% of dairy heifers in our study. Although we detected more ovulations on $\mathrm{d} 5$ than on any other day, our GnRH-induced ovulatory response was less than that observed in earlier studies. Although others suggested heifers tend to

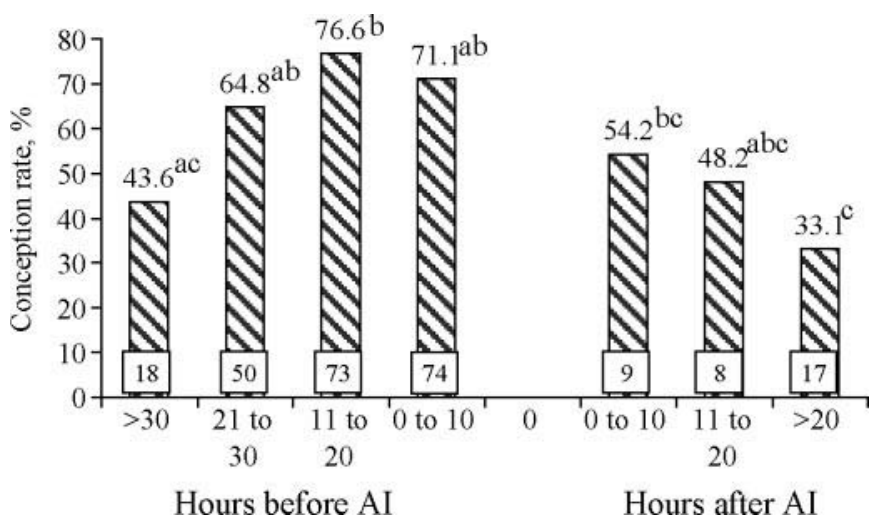

Figure 6. Conception rates (least squares means) in relation to onset of estrus and timing of semen placement in heifers receiving AI. Numbers of heifers for each bar are shown in the boxes. ${ }^{a-c}$ Bars having different letters differ $(P<0.05)$.

have a lesser ovulatory response to $\mathrm{GnRH}$ than cows because of shorter follicular waves and dominant follicles of lesser maximum diameter (Pursley et al., 1995; Adams, 1999), a major difference in our study was the concurrent inclusion of a progesterone insert at the time of GnRH injection in all but controls.

Concentrations of progesterone subsequent to progesterone treatment increase rapidly in ovariectomized cows, and concentrations exceeded $1 \mathrm{ng} / \mathrm{mL}$ within 5 min of insertion (Rathbone et al., 2002) and peaked by $2 \mathrm{~h}$. These increasing concentrations in our heifers, despite presence of a CL, may have inhibited GnRHinduced LH release and reduced ovulation success. Evidence for reduced ovulatory response to GnRH was reported in lactating dairy cows treated simultaneously with $\mathrm{GnRH}$ and a progesterone insert (Stevenson et al., 2008). In cows in which no insert was used, GnRH induced ovulation in $77 \%$ of 69 cows compared with $47 \%$ of 104 concurrently progesterone-treated cows or $43 \%$ of 604 cows having at least 1 CL. Steroid milieu is known to influence GnRH-induced LH release. Generally, increased peripheral concentrations of progesterone inhibit and those of estradiol (in absence of progesterone) increase GnRH-induced LH release (Price and Webb, 1988). Despite this evidence, in the present study, direct comparison of ovulatory response of control heifers (no progesterone; 29.2\%; $\mathrm{n}=48$ ) with the combined response $(23.7 \%$; $=93)$ of $\mathrm{GnRH}+$ early $\mathrm{PGF}$ and $\mathrm{GnRH}+$ late PGF does not indicate a major inhibition of concurrent progesterone administration of ovulatory response in heifers.

Recently, no relationship was detected between magnitude of GnRH-induced LH release and ovulation in heifers at known stages of the estrous cycle (Atkins et al., 2008). The previous authors suggested that physiological status of the dominant follicle may be a more 
Table 4. Pregnancies per $\mathrm{AI}^{1}(\mathrm{P} / \mathrm{AI})$ in response to treatment with $\mathrm{GnRH}$, progesterone, and $\mathrm{PGF}_{2 \alpha}$ after detected estrus or timed AI (TAI)

\begin{tabular}{|c|c|c|c|}
\hline \multirow[b]{2}{*}{ Item } & \multicolumn{3}{|c|}{$\% \mathrm{P} / \mathrm{AI}$ (no.) } \\
\hline & Estrus & TAI & Total \\
\hline \multicolumn{4}{|l|}{ Treatment $^{2}$} \\
\hline Early $\mathrm{PGF}_{2 \alpha}$ & $53.3(15)$ & $40.0(40)$ & $43.6^{\mathrm{x}}(55)$ \\
\hline GnRH + Early PGF $_{2 \alpha}$ & $50.0(16)$ & $42.5(40)$ & $44.6^{\mathrm{x}}(56)$ \\
\hline Late $\mathrm{PGF}_{2 \alpha}$ & $42.9(7)$ & $54.2(48)$ & $52.7^{\mathrm{x}}(55)$ \\
\hline GnRH + Late $\mathrm{PGF}_{2 \alpha}$ & $63.6(11)$ & $49.0(49)$ & $51.7^{\mathrm{x}}(60)$ \\
\hline Control & $75.0(8)$ & $30.4(46)$ & $37.0^{\mathrm{y}}(54)$ \\
\hline Total & $56.1^{\mathrm{a}}(57)$ & $44.0^{\mathrm{b}}(223)$ & $46.4(280)$ \\
\hline Early $\mathrm{PGF}_{2 \alpha}$ & $51.6(31)$ & $41.3(80)$ & $44.1(111)$ \\
\hline Late $\mathrm{PGF}_{2 \alpha}$ & $55.6(18)$ & $51.5(97)$ & $52.2(115)$ \\
\hline \multicolumn{4}{|l|}{ Day of estrous cycle ${ }^{3}$} \\
\hline 2 & $66.7(6)$ & $34.7(49)$ & $38.2(55)$ \\
\hline 5 & $33.3(3)$ & $37.9(58)$ & $37.7(61)$ \\
\hline 10 & $66.7(9)$ & $65.2(46)$ & $65.4(55)$ \\
\hline 15 & $62.5(16)$ & $42.5(40)$ & $48.2(56)$ \\
\hline 18 & $47.8(23)$ & $36.7(30)$ & $41.5(53)$ \\
\hline
\end{tabular}

${ }^{\mathrm{a}, \mathrm{b}}$ Mean percentages within row having different superscript letters differ $(P<0.05)$.

${ }^{\mathrm{x}, \mathrm{y}}$ Mean percentages within column having different superscript letters differ $(P<0.05)$.

${ }^{1}$ Determined by transrectal ultrasonographic evidence of fluid, embryonic heart beat, and presence of a corpus luteum at 32 to $33 \mathrm{~d}$ postTAI.

${ }^{2}$ All treatments except control included a 7-d insert with or without a concurrent injection of GnRH, and $\mathrm{PGF}_{2 \alpha}$ was given at either insert removal or $24 \mathrm{~h}$ earlier. Control heifers received GnRH followed in $7 \mathrm{~d}$ by $\mathrm{PGF}_{2 \alpha}$.

${ }^{3}$ Stage of estrous cycle at onset of treatment.

important factor determining ovulatory response than magnitude of the GnRH-induced LH release. Diameter of the follicles present at GnRH injection in our study did not limit ovulatory response because diameters of the largest follicle did not differ between heifers that ovulated and those that did not. If ovulation occurs after an injection of $\mathrm{GnRH}$, a new follicular wave is initiated within 48 h (Pursley et al., 1995; Vasconcelos et al., 1999; Moreira et al., 2000) and thus precludes formation of persistent follicles and their less fertile oocytes when the CL regresses spontaneously early during progestin treatment in late-cycle heifers (Savio et al., 1993; Revah and Butler, 1994; Mihm et al., 1999). Despite that potential, reduced fertility did not occur in dairy and beef heifers in which a progesterone insert was used without GnRH upfront (Richardson et al., 2002; Lamb et al., 2006) or in the present study (Table 4). As long as a CL is viable during the entire progestin treatment, normal follicle turnover occurs without a decline in fertility (Smith and Stevenson, 1995). In absence of a CL, persistent follicles can form in the presence of a progestin. Duration of dominance of a preovulatory follicle influences subsequent onset of estrus and fertility in heifers (Austin et al., 1999). Restricting duration of dominance of the potential preovulatory follicle to $\leq 4 \mathrm{~d}$ at estrus in the latter study resulted in a more precise onset of estrus and potentially improved fertility.
Growth of follicles during treatment was affected by the upfront $\mathrm{GnRH}$ injection regardless whether ovulation occurred. Although diameter of the largest follicle was smaller in progesterone insert treatments also receiving $\mathrm{GnRH}$ on $\mathrm{d} 2(48 \mathrm{~h}$ after $\mathrm{GnRH})$ than in non-GnRH, progesterone-treated heifers, compensatory growth occurred during the next $5 \mathrm{~d}$; hence, no differences were detected by $\mathrm{d} 7$ and 9 .

Injection of upfront GnRH tended to increase concentrations of progesterone by $6 \mathrm{~d}$ postinjection in progesterone-treated heifers despite the relative increase in progesterone in all insert-treated heifers compared with controls (Figure 2). Few studies have reported increases in serum concentrations of cattle treated with a progesterone insert when a CL was present (Richardson et al., 2002; Stevenson et al., 2003; Howard et al., 2006). But consistent with the trend observed in the present experiment, greater progesterone was detected in progesterone-treated beef and dairy heifers 6 d after GnRH compared with no progesterone insert, GnRH-treated controls. Further, in progesterone-insert treated beef heifers, compared with saline, GnRH injection increased serum progesterone $7 \mathrm{~d}$ later (Howard et al., 2006).

Earlier decrease in progesterone in early PGF heifers did not result in earlier expression of estrus as observed previously (Smith et al., 1984). The variance associ- 
ated with those intervals to estrus after insert removal was less than for controls (Figure 5) but did not differ among early- and late-PGF heifers, despite a small, nonsignificant difference of $8 \mathrm{~h}$ in the interval to estrus after insert removal (Table 3). This small difference in interval to estrus, despite similar variance, should be taken into account when determining interval to TAI. When performing TAI at $64 \mathrm{~h}$ after insert removal in the current study, heifers treated with $\mathrm{PGF}_{2 \alpha}$ concurrent with insert removal seemed to have greater $\mathrm{P} / \mathrm{AI}$ by 10.2 percentage points (Table 4 ).

Upfront injection of GnRH increased estrual activity posttreatment as assessed by increased duration of estrus, and number and duration of total standing events (Table 3) indicated that follicles may have been more estrogenic and stimulated more sexual behavior. In contrast, upfront injection of GnRH had no effect on the distribution (Figure 5) or interval to estrus (Table 3), in agreement with a large, multi-site study of beef heifers (Lamb et al., 2006). In an earlier study (Richardson et al., 2002), we reported that dairy heifers receiving a 7 -d progesterone insert concurrent with or without GnRH injection and early $\mathrm{PGF}_{2 \alpha}$ injection $24 \mathrm{~h}$ before insert removal had longer intervals to estrus than those receiving $\mathrm{GnRH}$ and $6 \mathrm{~d}$ before $\mathrm{PGF}_{2 \alpha}$. Heifers in the present study in later stages of the cycle at treatment initiation had early luteolysis, shorter intervals to estrus (cycle d 15), and poorer luteal regression (i.e., cycle d 15 and 18).

Relationship between onset of estrus and semen placement indicated that the best $\mathrm{P} / \mathrm{AI}$ occurred when onset of estrus occurred 30 to $0 \mathrm{~h}$ before AI, confirming earlier observations in dairy heifers treated with a $7-\mathrm{d}$ PRID and $\mathrm{PGF}_{2 \alpha} 24 \mathrm{~h}$ earlier or 2 injections of $\mathrm{PGF}_{2 \alpha}$ $11 \mathrm{~d}$ apart (Smith et al., 1984). In that study, poor P/ AI were achieved when first detected estrus occurred 25 to $40 \mathrm{~h}$ before or 4 to $20 \mathrm{~h}$ after AI compared with AI between 0 and $25 \mathrm{~h}$ after first detected estrus. Earlier we (Richardson et al., 2002) reported that conception rates were greatest in heifers inseminated $>16 \mathrm{~h}$ after the onset of estrus as determined by electronic estrusdetection patches.

In summary, ovulatory response to $\mathrm{GnRH}$ was poor and similar regardless whether $\mathrm{GnRH}$ administration was concurrent with progesterone. Injection of $\mathrm{GnRH}$ resulted in smaller follicle diameters $2 \mathrm{~d}$ after treatment, but compensation in rate of follicle growth produced follicles of similar size $7 \mathrm{~d}$ later. Injection of GnRH tended to increase serum progesterone at d 6 after onset of treatment but had no effect of interval to or duration of estrus. In contrast, GnRH-treated heifers received more mounts of greater duration during estrus. Pregnancies per AI were reduced in heifers receiving TAI at $64 \mathrm{~h}$ after insert removal compared with those inseminated after detection of estrus. The $\mathrm{P} / \mathrm{AI}$ were less in controls not treated with progesterone. Administration of progesterone resulted in a more consistent and less variable pattern of estrus distribution compared with controls. Heifers initiating treatment on d 10 seemed to have the best $\mathrm{P} / \mathrm{AI}$ regardless whether inseminated after estrus or by appointment at $64 \mathrm{~h}$ after insert removal. No difference in average or variance of interval to estrus after insert removal regardless of whether $\mathrm{PGF}_{2 \alpha}$ was injected at or $24 \mathrm{~h}$ before insert removal justifies concurrent insert removal and $\mathrm{PGF}_{2 \alpha}$ injection. Although nonsignificant, $\mathrm{P} / \mathrm{AI}$ favored that management choice.

\section{REFERENCES}

Adams, G. P. 1999. Comparative patterns of follicle development and selection in ruminants. J. Reprod. Fertil. Suppl. 54:17-32.

Atkins, J. A., D. C. Busch, J. F. Bader, D. H. Keisler, D. J. Patterson, M. C. Lucy, and M. F. Smith. 2008. Gonadotropin-releasing hormone-induced ovulation and luteinizing hormone release in beef heifers: Effect of day of the cycle. J. Anim. Sci. 86:83-93.

Austin, E. J., M. Mihm, M. P. Ryan, D. H. Williams, and J. F. Roche. 1999. Effect of duration of dominance of the ovulatory follicle on onset of estrus and fertility in heifers. J. Anim. Sci. 77:2219 2226 .

Hansel, W., and W. E. Beal. 1979. Ovulation control in cattle. Pages 91-110 in Animal Reproduction 3. Beltsville Symposium in Agricultural Research. H. W. Hawk, ed. Allenheld, Osmun and Co., Montclair, NJ

Howard, J. M., D. G. Falk, K. G. Carnahan, J. C. Dalton, R. C. Chebel, T. C. Blair, and A. Ahmadzadeh. 2006. The use of a progesterone releasing device (CIDR), with $\mathrm{GnRH}$ and prostaglandin $\mathrm{F} 2 \alpha$ $(\mathrm{PGF})$, for a fixed-time artificial insemination in beef heifers. J. Anim. Sci. 81(Suppl. 1):51. (Abstr.)

Lamb, G. C., J. E. Larson, T. W. Geary, J. S. Stevenson, S. K. Johnson, M. L. Day, R. P. Ansotegui, D. J. Kesler, J. M. DeJarnette, and D. G. Landblom. 2006. Synchronization of estrus and artificial insemination in replacement beef heifers using gonadotropinreleasing hormone, prostaglandin F2alpha, and progesterone. J. Anim. Sci. 84:3000-3009.

Lamb, G. C., J. S. Stevenson, D. J. Kesler, H. A. Garverick, D. R. Brown, and B. E. Salfen. 2001. Inclusion of an intravaginal progesterone insert plus $\mathrm{GnRH}$ and prostaglandin $\mathrm{PGF}_{2 \alpha}$ for ovulation control in postpartum suckled beef cows. J. Anim. Sci. $79: 2253-2259$.

Mihm, M., N. Curran, P. Hyttel, P. G. Knight, M. P. Boland, and J. F. Roche. 1999. Effect of a dominant follicle persistence on follicular fluid estradiol and inhibin and on oocyte maturation in heifers. J. Reprod. Fertil. 116:293-304.

Moreira, F., R. L. de la Sota, T. Diaz, and W. W. Thatcher. 2000. Effect of day of the estrous cycle at the initiation of a timed artificial insemination protocol on reproductive responses in dairy heifers. J. Anim. Sci. 78:1568-1576.

National Research Council. 2001. Nutrient Requirements of Dairy Cattle. 7th rev. ed. Natl. Acad. Sci., Washington, DC.

Nebel, R. L., and S. M. Jobst. 1998. Evaluation of systematic breeding programs for lactating dairy cows: A review. J. Dairy Sci. 81:1169-1174.

Patterson, D. J., F. N. Kojima, and M. F. Smith. 2003. A review of methods to synchronize estrus in replacement beef heifers and postpartum cows. J. Anim. Sci. 81(E Suppl.):E166-E177.

Price, C. A., and R. Webb. 1988. Steroid control of gonadotropin secretion and ovarian function in heifers. Endocrinology 122:22222231.

Pursley, J. R., M. O. Mee, and M. C. Wiltbank. 1995. Synchronization of ovulation in dairy cows using $\mathrm{PGF}_{2 \alpha}$ and $\mathrm{GnRH}$. Theriogenology 44:915-923. 
Pursley, J. R., M. C. Wiltbank, J. S. Stevenson, J. S. Ottobre, H. A Garverick, and L. L. Anderson. 1997. Pregnancy rates per artificial insemination for cows and heifers inseminated at a synchronized ovulation or synchronized estrus. J. Dairy Sci. 80:295-300.

Rathbone, M. J., R. R. Bunt, C. R. Ogle, S. Burggraaf, K. L. Macmillan, C. R. Burke, and K. L. Pickering. 2002. Reengineering of a commercially available bovine intravaginal insert (CIDR insert) containing progesterone. J. Control. Release 85:105-115.

Revah, I., and W. R. Butler. 1994. Prolonged dominance of follicles and reduced viability of bovine oocytes. J. Reprod. Fertil. 106:3947.

Richardson, A. M., B. A. Hensley, T. J. Marple, S. K. Johnson, and J. S. Stevenson. 2002. Characteristics of estrus before and after first insemination and fertility of heifers after synchronized estrus using GnRH, $\mathrm{PGF}_{2 \alpha}$, and progesterone. J. Anim. Sci. 80:2792-2800.

Savio, J. D., W. W. Thatcher, G. R. Morris, K. Entwistle, M. Drost, and M. R. Mattiacci. 1993. Effects of induction of low plasma progesterone concentrations with a progesterone-releasing intravaginal device on follicular turnover and fertility in cattle. J. Reprod. Fertil. 98:77-84.

Skaggs, C. L., B. V. Able, and J. S. Stevenson. 1986. Pulsatile or continuous infusion of luteinizing hormone-releasing hormone and hormonal concentrations in prepubertal beef heifers. J. Anim. Sci. 62:1034-1048.

Smith, M. W., and J. S. Stevenson. 1995. Fate of the dominant follicle, embryonal survival, and pregnancy rates in dairy cattle treated with prostaglandin $\mathrm{F}_{2 \alpha}$ and progestins in the absence or presence of a functional corpus luteum. J. Anim. Sci. 73:3743-3751.
Smith, R. D., A. J. Pomerantz, W. E. Beal, J. P. McCann, T. E. Pilbeam, and W. Hansel. 1984. Insemination of Holstein heifers at a preset time after estrous cycle synchronization using progesterone and prostaglandin. J. Anim. Sci. 58:792-800.

Stevenson, J. S., G. C. Lamb, S. K. Johnson, M. A. Medina-Britos, D. M. Grieger, K. R. Harmoney, J. A. Cartmill, S. Z. El-Zarkouny, C. R. Dahlen, and T. J. Marple. 2003. Supplemental norgestomet, progesterone, or melengestrol acetate increases pregnancy rates in suckled beef cows after timed inseminations. J. Anim. Sci. $81: 571-586$.

Stevenson, J. S.. J. F. Smith, and D. E. Hawkins. 2000. Reproductive outcomes for dairy heifers treated with combinations of prostaglandin $\mathrm{F}_{2 \alpha}$, norgestomet, and gonadotropin-releasing hormone. J. Dairy Sci. 83:2008-2015.

Stevenson, J. S., D. E. Tenhouse, R. L. Krisher, G. C. Lamb, J. E. Larson, C. R. Dahlen, J. R. Pursley, N. M. Bello, P. M. Fricke, M. C. Wiltbank, D. J. Brusveen, M. Burkhart, R. S. Youngquist, and H. A. Garverick. 2008. Detection of anovulation by heatmount detectors and transrectal ultrasonography before treatment with progesterone in a timed insemination protocol. J. Dairy Sci. 91:2901-2915.

Vasconcelos, J. L., R. W. Silcox, G. J. Rosa, J. R. Pursley, and M. C. Wiltbank. 1999. Synchronization rate, size of the ovulatory follicle, and pregnancy rate after synchronization of ovulation beginning on different days of the estrous cycle in lactating dairy cows. Theriogenology 52:1067-1078. 